Работа в терапевтической группе строится по принципу гештальт - терапии «здесь и теперь», но при этом практически в любой транзакции между участниками отражаются факты из прошлого. Поэтому работа в группе позволяет проработать проблемные области, дает обильный материал для анализа. Каждый участник такой формы работы приобретает новый опыт [5], а также, под руководством консультанта, может выявить свой негативный сценарий.

При этом сам консультант обязательно должен отслеживать свои психологические потребности и состояние, соблюдать правильное соотношение своих эго-состояний: Родитель защищает и заботится, Ребенок радуется и творчески мыслит, а Взрослый анализирует и предоставляет информацию. Иначе терапии не получится, а клиенты могут выйти после консультации травмированными.

Во время работы в терапевтической группе важно уделять внимание следующим компонентам:

1) Стремление клиентов к здоровью;

2) Оказание воздействия на участников;

3) Правильное поведение консультанта;

4) Прошлый опыт участников.

Терапевты в групповом процессе применяют как свою интуицию, так и формализованные приёмы.

Вывод. Таким образом, подход к психологическому консультированию с позиции транзактного анализа является эффективным, решает широкий спектр вопросов и может осуществляться как в индивидуальной, так и в групповой форме. При этом крайне важно, чтобы квалификация консультанта была высокой.

$$
* * *
$$

1. Антонова Н.В. Консультирование и коучинг персонала в организации: учебник и практикум для бакалавриата и магистратуры / Н. В. Антонова [и др.]; под редакцией Н. В. Антоновой, Н. Л. Ивановой. - Москва : Издательство Юрайт, 2017. - 370 с.

2. Берн Э. Игры, в которые играют люди. Люди, которые играют в игры. М, Прогресс, 1985

3. Берн Э. Трансактный анализ в группе. М, Лабиринт, 1994

4. Берн Э. Трансакционный анализ и психотерапия. СПб, Братство, 1992

5. Гулина М.А. Терапевтическая и консультативная психология. - СПб., 2001.

6. Макарова Г.А. Лекция по применению трансактного анализа в психологическом консультировании / Г.А. Макарова // Научно-практический журнал "Вопросы ментальной медицины и экологии", т. VIII, №2, 2002

7. Родермель Т.А., Капущак И.В. Психологические проблемы виктимного клиента и психологическое консультирование с элементами коучинга.//: Annali d'Italia (Italy's scientific journal) is a peer-reviewed European journal covering top themes and problems in various fields of science. VOL.3 2020 (7).- C.-65-69

8. Стюарт Я., Джойнс В. Современный трансактный анализ. СПб, Соц.-психол. центр, 1996

9. Чусовитин А., Родермель Т.А., Психологическое консультирование сотрудников пенитенциарной системы, испытывающих виктимность / А. Чусовитин, Т.А.Родермель//: Znanstvena misel journal The journal is registered and published in Slovenia. - №42, (VOL. 3)- 2020. - C 52-56

\title{
Слабожанина Е.О. \\ Взаимосвязь механизмов психологических защит и акцентуаций характера у студентов
}

Новокузнеикий институт (филиал) ФГБОУ ВО «Кемеровский государственный университет»

doi: $10.18411 / \mathrm{j}-05-2021-302$

(Россия, Новокузнеик)

\section{Аннотация}

В данной статье рассматривается вопрос о взаимосвязи механизмов психологических защит и акцентуаций характера у студентов-психологов. Рассмотрены 
разные подходы к понятиям: «акцентуации характера», «психологические защиты», «студенчество», «юношеский возраст».

Ключевые слова: «психологическая защита», «акцентуация», «студент».

\section{Abstract}

This article discusses the relationship between the mechanisms of psychological defenses and character accentuations in psychology students. Different approaches to the concepts of «character accentuation», «psychological defenses», «students», «youth».

Keywords: «psychological protection», «accentuation», «students».

В современном мире безостановочно происходят изменения в различных сферах жизни людей. Окружающий нас мир модернизируется и дополняется новыми элементами, меняются условия и увеличиваются стрессовые ситуации в окружающем нас мире. Часто это приводит к использованию психологических защит, которые ограждают сознание от неприятных переживаний, обострению нервно-психических расстройств и граничащих с ними состояний, к которым относят, в частности акцентуации характера.

Впервые психологическая защита была выделена в русле психоанализа, и связан с именем Зигмунда Фрейда. Данный термин употребляется в его труде «Защитные нейропсихозы», который был издан в 1894 году. В нем автор изложил назначение психологической защиты, заключающееся в ослаблении конфликта между инстинктивными бессознательными влечениями и требованиями внешней среды[1].

Проблема психологической защиты активно рассматривается как в отечественной, так и в зарубежной литературе и определяется как:

- деятельность психики, направленная на спонтанное устранение последствий психической травмы (Ф. В. Бассин)[2];

- как система адаптивных реакций личности, направленная на защитное изменение значимости дезадаптивных компонентов отношений когнитивных, эмоциональных, поведенческих - с целью ослабления их психотравмирующего воздействия на Я-концепцию больного (Д. Б. Карвасарский)[3];

- совокупностью способов последовательного искажения когнитивной и аффективной составляющей образа реальной ситуации (Л. Р. Гребенников)[7];

- способов репрезентации искаженного смысла (В. Н. Цапкин)[1].

Также следует выделить взгляды Р. Плутчика, Г. Келлермана и Е. Мирошника, которые в качестве основных видов механизмов психологических защит выделили[8]: отрицание, подавление, регрессия, компенсация, проекция, замещение, интеллектуализация, реактивное образование[10].

Р. Плутчик составил классификацию защит по критерию примитивностизрелости. Онтогенетически первыми возникают защиты, базирующиеся на перцептивных процессах: ощущении, внимании, восприятии, их функционирование связано с невидением, неприятием информации. К этой группе Р. Плутчик относил отрицание, проекцию, регрессию и их аналоги. Позже возникают защиты, основанные на процессах памяти: вытеснение и подавление. Наиболее сложными, зрелыми и конструктивными защитами являются замещение, компенсация и интеллектуализация[14].

Для раскрытия темы необходимо рассмотреть такое понятие как “акцентуация характера".

Понятие «акцентуация» впервые ввел немецкий психиатр и психолог, профессор неврологии, неврологической клиники Берлинского университета Карл Леонгард, автор 
концепции «акцентуированных личностей», которая послужила теоретической основой для создания личностного опросника, разработанного в 1970 году другим немецким психиатром и психологом - Г. Шмишеком[9].

Согласно концепции К. Леонгарда об акцентуированных личностях, черты каждой личности могут быть разделены на две группы: основную и дополнительную. Основных черт значительно меньше, но они являются стержнем личности, определяют ее развитие, адаптацию и психическое здоровье. При большой степени выраженности основных черт они накладывают отпечаток на личность в целом и при неблагоприятных социальных условиях могут разрушить структуру личности[12].

Немецкий психолог Э. Кречмер в своей знаменитой работе «Строение тела и характер» попытался найти те связи, которые существуют между строением тела человека и его психическим складом. На основе большого объема клинических наблюдений он пришел к выводу: тип телосложения предопределяет не только формы психических заболеваний, но и наши основные личностные (характерные) особенности[11].

Также проблему акцентуации характера рассматривал в своих работах А. Е. Личко: “Акцентуация - это чрезмерное усиление отдельных черт характера, при котором наблюдаются не выходящие за пределы нормы отклонения в психологии и поведении человека, граничащие с патологией”. Такие акцентуации как временные состояния психики чаще всего наблюдаются в подростковом и юношеском возрасте[10].

Рассмотрим теоретические предпосылки исследования юношеского возраста в зарубежной и отечественной литературе.

Юношеский возраст - период индивидуальной жизни, в котором становится (развивается) способность деятельно, практически соотносить цели, ресурсы и условия для решения задач строительства собственной жизни, перспективы, характерной для взрослого человека[12].

Центральными психическими процессами юношеского возраста являются развитие сознания и самосознания. Развитию самосознания Л. С. Выготский отводил в юности большую роль: “В этом возрасте происходит открытие «Я», собственного мира мыслей, чувств, переживаний, которые кажутся самому субъекту неповторимыми и оригинальными; развитие рефлексии обуславливает критическую переоценку ранее сложившихся ценностей и смысла жизни - возможно, их изменение и дальнейшее развитие"[22].

В психологических периодизациях Д. Б. Эльконина и А. Н. Леонтьева ведущей деятельностью в юности считается учебно-профессиональная деятельность. Ведущее место занимают мотивы, связанные с самоопределением и подготовкой к самостоятельной жизни с дальнейшим образованием и самообразованием[13].

Студенчество в качестве отдельной возрастной и социально-психологической категории выделилось в науке в 1960-х годах Ленинградской психологической школой под руководством Б. Г. Ананьева, при исследовании психофизиологических функций взрослых людей. Как возрастная категория, студенчество соотносится с этапами развития взрослого человека, представляя собой «переходную фазу от созревания к зрелости» и определяется как поздняя юность - ранняя взрослость (18-25 лет)[19].

Рассматривая студенчество как «особую социальную категорию, специфическую общность людей, организованно объединенных институтом высшего образования», И. А. Зимняя выделяет основные характеристики студенческого возраста, отличающие его от других групп населения высоким образовательным уровнем, высокой познавательной мотивацией, наивысшей социальной активностью и достаточно гармоничным сочетанием интеллектуальной и социальной зрелости[20]. 
Исследование взаимосвязи механизмов психологических защит и акцентуаций характера проводилось среди студентов юношеского возраста - 27 человек, обучающихся в НФИ КемГУ г. Новокузнецк, по специальности "Психология служебной деятельности".

Было проведено исследование с помощью следующих методик:

1. Тест-опросник "Методика акцентуации характера и темперамента личности” К. Леонгарда (модификация С. Шмишека);

2. Тест-опросник механизмов психологической защиты "Индекс жизненного стиля”, «Life style index» (LSI) (P. Плутчик, Г. Келлерман, Х.Р. Конте, адаптация Е.С. Романова, Л.Р. Гребенников).

1. В исследуемой группе у большинства испытуемых преобладающим механизмом психологической защиты является - интеллектуализация (25,93\%). Данный результат свидетельствует о том, что студентам свойственно преувеличенное использование интеллектуальных ресурсов в целях устранения эмоциональных переживаний и чувств, путем размышлений о них. У $14,81 \%$ испытуемых преобладающими механизмами психологической защиты являются - регрессия и компенсация. Это характеризует их как людей, которые стремятся избежать тревоги путем перехода на более ранние стадии развития либидо, т.е. возврат к детским моделям поведения, а также людей, которые находят подходящую замену реального или воображаемого недостатка, чаще всего с помощью фантазирования или присвоения себе свойств, достоинств другой личности. А у наименьшего количества испытуемых $(3,7 \%)$ преобладающими механизмами психологической защиты являются - замещение и реактивное образование. Характеризует людей, которым свойственно переносить действия, направленные с недоступного объекта на доступный, a также преобразовывать негативные чувства в позитивные либо наоборот, при этом осознавая первоначальную негативную эмоцию.

2. В исследуемой группе большинство респондентов имеют акцентуацию характера по шкале «эмотивность» - 53,8\%. Это свидетельствует о достаточной чувствительности людей, способных проявлять чувства и сострадание по отношению к окружающим. Акцентуацией характера по шкале “гипертимность” обладают $35,6 \%$. У большинства респондентов преобладает ровное и повышенное настроение, они открыты с близкими, но не проявляют чрезмерную инициативу в общении. 10,6\% респондентов обладают акцентуаций характера по шкале “циклотимность". Характеристика большинства респондентов по данному типу акцентуации представляет собой следующее: настроение устойчивое, отсутствуют резкие беспричинные спады и циклическая смена поведения.

По шкале дистимной акцентуации характера 100\% испытуемых имеют средний уровень выраженности. Ни у кого из респондентов акцентуация характера по данному типу выявлена не была.

В ходе всего исследования был выбран такой метод, как математический анализ по X. Пирсону. По результатам корреляционного анализа данных "Методика акцентуации характера и темперамента личности" К. Леонгарда (модификация С. Шмишека) и психодиагностическому тестированию "Индекс жизненного стиля", «Life style index» (LSI) (Р. Плутчик, Г. Келлерман, Х.P. Конте, адаптация Е.С. Романова, Л.Р. Гребенников) можно сделать вывод о том, что значимой взаимосвязи между механизмами психологических защит и акцентуациями характера в исследуемой группе нет.

Согласно полученным данным, гипотеза о том, что существует значимая взаимосвязь между механизмами психологических защит и акцентуациями характера у студентов, а именно, чем ярче выражены конструктивные психологические защиты, 
тем менее выражен дистимический и более выражен гипертимный тип акцентуации характера, не подтверждается.

$$
* * *
$$

1. Х Хьелл, Л. Теории личности / Л. Хьелл, Д. Зиглер. - 2-е изд., стереотип. - СПб.: Питер, 2008. 607 с. - ISBN 68-904-0072-6. - Текст : непосредственный.

2. Бассин, Ф. В. О силе «Я» и психологической защите // Вопросы философии. - М., 1969. - №2. - С. 118 - 126. - ISBN 12-901-0472-11. - Текст : непосредственный.

3. Психотерапевтическая энциклопедия / под ред. Б. Д. Карвасарского. - 3-е изд., перераб. и доп. СПб.: Питер, 1998. - 752 с. - ISBN 77-914-0172-6. - Текст : непосредственный.

4. Сараева, Е. В. Защитные механизмы личности: учеб. пособие. - Киров : ВятГГУ, 2007. - 101 с. ISBN 4-910-0072-1. - Текст : непосредственный.

5. Нуллер Ю. Л. Деперсонализация защитная реакция и психопатологический синдром // Эмоциональный стресс и пограничные нервно-психические расстройства. Л., 1977. - С. 124-134. ISBN 4-910-0072-1. - Текст : непосредственный.

6. Бобнев М. И. Психологические проблемы социальной регуляции поведения / Отв. ред. Е.В. Шорохова, М., 1976. - 368 с. - Текст : непосредственный.

7. Романова Е. В., Гребенников Л. Р. Механизмы психологической защиты: генезис, функционирование, диагностика. - Мытищи: Издательство «Талант», 1996. - 144 с. - ISBN 4-9100072-1. - Текст : непосредственный.

8. Райгородский Д. Я. Самосознание и защитные механизмы личности: хрестоматия. - Самара: ИД «Бахрам-М», 2006. - 609 с. - Текст : непосредственный.

9. Dodiplom.ru: электронный сайт. - URL http://dodiplom.ru/ready/110210 (дата обращения 12.12.2020). - Текст: электронный.

10. Ineych: электронный справочник для студентов. - URL https://www.yaneuch.ru/cat_18/podhody-kissledovaniju-akcentuacii-haraktera/421623.2816746.page1.html (дата обращения 12.12.2020). - Текст: электронный.

11. Студопедия: электронный справочник для студентов. - URL https://studopedia.su/14_125226_tipologiya-ekrechmera.html (дата обращения 12.12.2020). - Текст: электронный.

12. Столяренко Л. Д. Основы психологии. — Р /наД.: Феникс, 1997. — С. 736.

13. Зимняя И. А. Педагогическая психология: уч. для студентов по пед. и психол. направ. и спец. М.: Логос, 2000. - С. 384.

14. Романова Е. С., Гребенников Л. Р. Механизмы защиты как специфические средства решения универсальных проблем адаптации // Самосознание и защитные механизмы личности. Хрестоматия. - Самара: 2003. - С. 563-593.

\section{Толкач И.Ф. \\ Общая эмоциональная направленность студентов инженерных специальностей}

УО «Белорусский государственный аграрный технический университет» (Беларусь, Минск)

doi: $10.18411 / \mathrm{lj}-05-2021-303$

\section{Аннотация}

Статья посвящена изучению общей эмоциональной направленности студентов инженерных специальностей. В соответствии со средними значениями выявлено преобладание праксической, романтической, пугнической и коммуникативной направленностей студентов. Недостаточно высокие результаты показаны по гедонистической, гностической, альтруистической, глорической, эстетической и акизитивной шкалам. В качестве ведущей студентами обозначены праксическая, коммуникативная, гедонистическая и романтическая эмоциональные направленности.

Ключевые слова: эмоциональная направленность, студенты.

\section{Abstract}

The article is devoted to the study of the general emotional orientation of engineering students. In accordance with the average values, the predominance of the students' praxic, romantic, pugnistic and communicative orientations are revealed. Insufficient results are 